\title{
Another Seawater Desalination Process
}

\author{
Guyteau Bayard \\ 14856 Labelle Street Pierrefonds (Québec) Canada H9H $1 \mathrm{J3}$
}

\begin{abstract}
This method of desalination basically applies the possibilities of the laws of inorganic chemistry precisely the laws of the precipitation to desalinate any water containing salt, with priority for seawater, the most abundant source of water on authors' planet. It is good to remember that the industry has always used these laws for the preparation of certain compounds. As the previous methods, rather than consuming energy such as reverse osmosis, distillation and electro dialysis, it requires no energy. On the contrary, recycling used products delivers power.
\end{abstract}

Key words: Water, potassium, energy.

\section{Introduction}

The needs for water to stimulate more efficient and less polluting agricultural production are produced at the same time, and the need for energy in recent decades have continued to rise, in order to cope with the difficulty for controlling world population growth. All the experts or demographers expect that the situation will remain until around the years 2030-2040. This problematic situation have already made other situations too complicated, and author wants to mention the climate issues, in which desertification caused by drought is one of the most obvious evidences. Concerning about the situation that threatens everyone, researchers around the world have developed ingenious solutions to draw water from the sea, including evaporation pressure, reverse osmosis, ion exchange resins and the latest one, desalination using solar energy. In addition to these useful but sophisticated solutions, author proposes a new technique that is much easier and more accessible, able to provide energy in addition to water.

\section{Materials and Methods}

Seawater $=\mathrm{H}_{2} \mathrm{O}+$ salts as mentioned below, and high $\mathrm{pH}$

$\mathrm{Na}^{+}$ions $(30.59 \%)+\mathrm{Mg}^{2+}$ ions $(3.73 \%)+\mathrm{Ca}^{2+}$ ions

Corresponding author: Guyteau Bayard, bachelor, main research field: desalting of seawater.
$(1.20 \%)+\mathrm{K}^{+}$ions $(1.11 \%)+\mathrm{Cl}^{-}$ions $(55.29 \%)+$ $\mathrm{SO}_{4}{ }^{2-}$ ions $(7.69 \%)$ Bromide, carbonate, fluoride and iodide was in very small proportion [1] aluminum fluoride $\mathrm{AlF}_{3}$ lead fluoride $\mathrm{PbF}_{2}$.

\subsection{Stabilization of the Solution}

Materials used such as $\mathrm{Al}^{3+}$ need stability. The $\mathrm{pH}$ of the marine environment is high, between 7.5 and 9, but it must be reduced to 6.5 or 7 to prevent its precipitation as hydroxides $\mathrm{Al}(\mathrm{OH})_{3}$. This will be done with a little hydrofluoric acid HF or hydrochloric acid HCL that can be eliminated later.

\subsection{Start-Up and Operation}

The second approach is the addition of lead fluoride $\mathrm{PbF}_{2}$ and aluminum fluoride $\mathrm{ALF}_{3}$. The reactions, which we see, are the following; the slightly soluble $5 \mathrm{~g} / \mathrm{L}$ [2] aluminum salt fluoride dissolves slowly in seawater. From the time when there will be enough $\mathrm{Al}^{3+}$ ions, lead fluoride will tend to dissolve considering the appeal of the fluorine by aluminum and complex formation $\mathrm{ALF}^{2+}$. On the other hand, in the presence of $\mathrm{Na}^{+}$ions, it forms the complex anion $\mathrm{AlF}_{6}{ }^{3-}$ which will react to form cryolite according to Eq. (1):

$$
\mathrm{AlF}_{6}{ }^{3-}+3 \mathrm{Na}^{+} \rightarrow \mathrm{Na}_{3} \mathrm{AlF}_{6} \downarrow
$$

It should be noted at the same time that the ions $\mathrm{Cl}^{-}$ from the sea water became single after the precipitation of $\mathrm{Na}_{3} \mathrm{AlF}_{6}$. These charged ions $\mathrm{Cl}^{-}$seek to stabilize. Complex $\mathrm{Pb}$ and $\mathrm{Cl}$ are known [3], 
particularly $\mathrm{PbCl}^{+}$, although they are unstable. And immediately after the precipitation of the cryolite, the reaction was:

$$
\mathrm{PbCl}^{+}+\mathrm{F}^{-} \rightarrow \mathrm{PbClF} \downarrow
$$

Author also has insoluble lead sulphate $\mathrm{PbSO}_{4} \downarrow$ due to the $\mathrm{SO}_{4}{ }^{2-}$ ions as mentioned above (2 grams, 69 ) or $7.69 \%$, especially as lead sulfate is less soluble than PbCLF.

$$
\mathrm{Pb}^{2+}+\mathrm{SO}_{4}^{2-} \rightarrow \mathrm{PbSO}_{4} \downarrow
$$

At the same time calcium and magnesium precipitate:

$$
\begin{array}{r}
\mathrm{Ca}^{2+}+2 \mathrm{~F}^{-} \rightarrow \mathrm{CaF}_{2} \downarrow \\
\mathrm{Mg}^{2+}+2 \mathrm{~F}^{-} \rightarrow \mathrm{MgF}_{2} \downarrow
\end{array}
$$

\section{Results and Discussion}

\subsection{Characteristic}

As a result of the transformation of $\mathrm{Pb}^{2+}, \mathrm{Al}^{3+}, \mathrm{Cl}^{-}$ and $\mathrm{Na}^{+}$ions in Fluo-chloride and cryolite, unsafe drinking seawater totally got rid of its harmful salts, becoming enriched potassium potable.

\subsection{Purification and Recovery of Waste Ions}

And after the removal of $\mathrm{Al}, \mathrm{Pb}$ and $\mathrm{Na}$, exempting the environment ions waste will be considered, since no salt is completely insoluble and some heavy ions as lead are toxic. Magnesium itself found in the sea (Eq. 4) is the material of choice, and its introduction in the environment as sticks gives the following results without explosion:

$$
\begin{gathered}
2 \mathrm{Ag}^{+}+\mathrm{Mg} \rightarrow \mathrm{Mg}^{2+}+2 \mathrm{Ag} \downarrow \\
2 \mathrm{Al}^{3+}+3 \mathrm{Mg} \rightarrow 3 \mathrm{Mg}^{2+}+2 \mathrm{Al} \downarrow \\
\mathrm{Pb}^{2+}+\mathrm{Mg} \rightarrow \mathrm{Mg}^{2+}+\mathrm{Pb} \downarrow
\end{gathered}
$$

This purification after desalination of seawater offers interesting prospects for metallurgy, since each desalination operation will obtain all kinds of metals. As geologists estimate, there are 50 million tons of silver, more than a billion tons of titanium and other metals dissolved in the ocean [4].

\subsection{Analysis of Final Results}

With these rules formulated by Berthollet, author could eliminate all the undesirable salts that were in seawater. It is interesting to know the nature of bodies remaining. Arguably, there are $\mathrm{K}^{+}(0.38 \mathrm{~g})$ and $\mathrm{SO}_{4}{ }^{2-}$ ions to a mass of $0.90 \mathrm{~g}$ of potassium sulfate, when the salt concentration is $35 \mathrm{~g} / \mathrm{L}$. But the $\mathrm{SO}_{4}{ }^{2-}$ ions disappeared with lead (Eq. 3). Author will restore the balance later. The $\mathrm{K}^{+}$ions become single; in order to stabilize it, they will decompose water to produce hydrogen precious energy according to Eq. (9):

$2 \mathrm{~K}+2 \mathrm{H}_{2} \mathrm{O} \rightarrow 2 \mathrm{~K}^{+}+2 \mathrm{OH}^{-}+\mathrm{H}_{2} \uparrow$

And the question: what would be the best use to make this water become available or drinking?

Author thinks the first use would be for agriculture because obviously vital potassium for plants are becoming increasingly expensive. With a ratio of 5 liters of irrigation per $\mathrm{m}^{2}$ to 6 or 15 days, for an area of one hectare $\left(10,000 \mathrm{~m}^{2}\right)$, the amount of potassium to the soil is largely sufficient to meet the needs of any culture of $125 \mathrm{~kg} / \mathrm{ha} \mathrm{K}^{+}$[5]. Will author need nitrogen fertilizer? Author would say no, because the marine environment is full of bacteria, plankton and other living bodies [6]. On the ground once their bodies are decomposed by bacteria (nitrobacteria and others), making the nitrogenous substances necessary to plants [7], if insufficient special plants such as peanut and others including rhizobium can be upstream of all cultures. Will author need phosphorus fertilizer? Author still says no, because all these marine particles containing phosphorus. And more phosphorus is present in the sea in the balanced ratio of $0.06 \mathrm{mg} / \mathrm{L}$. Author can say that farming covered by the environmentalists is almost reached. And the economic aspect in this regard should not be overlooked. For example, any public or private company that desalted seawater in every $\mathrm{km}^{3}$ will squeeze into the sea about $900,000 \mathrm{t}$ of potassium sulfate at the present price near 1,000 dollars a ton. Although the price is currently down, it will be able to claim to farmers, and to finance its infrastructure (Fig. 1).

\subsection{Tracking Desalinated Water}

In practice after irrigation, half water used is not 
We assume this tank filled with seawater

$\mathrm{H}_{3} \mathrm{O}+\mathrm{NaCl}$

$\mathrm{H}_{2} \mathrm{O}+\mathrm{PbClF}$,

$\mathrm{PbF}_{2}+\mathrm{AlF}_{3}$

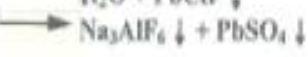
and there will be precipitation of cryolite, calcium fluoride lead su'phate, magnesium fluoride and PbCLF

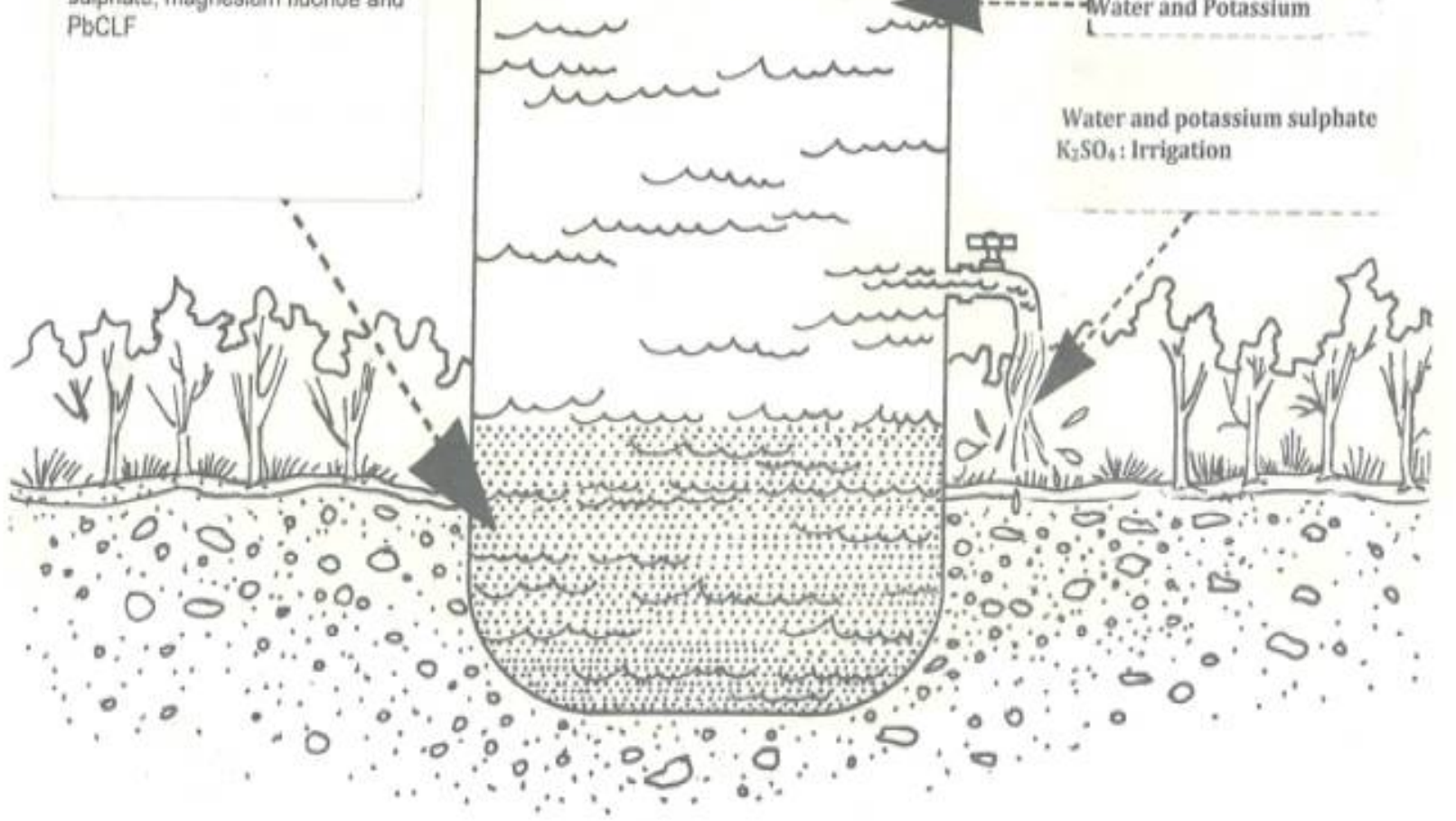

Fig. 1 An overview of the desalting operation.

absorbed by plants but goes into the depths where it will enrich the groundwater and be pumped to other uses.

\subsection{Detailed Study of the Energy That Can Provide the Desalination}

These are the data that author has compiled from his calculations. Firstly, this process requires 197 grams of $\mathrm{PbF}_{2}(0.80$ mole $)$ and 21 grams $82(0.2560$ mole) of $\mathrm{AlF}_{3}$, but author must add precisely more 0.52 mole because calcium and magnesium will absorb ions $\mathrm{F}^{-}$. Author clearly see the weight of lead of 208 compared to the 108 silver and 63.6 copper used in previous processes.

Author must treat the product of precipitation $\mathrm{Na}_{3} \mathrm{AlF}_{6}$ with sulphuric acid:

$$
\begin{gathered}
6 \mathrm{H}_{2} \mathrm{SO}_{4}+2 \mathrm{Na}_{3} \mathrm{AlF}_{6} \rightarrow \\
3 \mathrm{Na}_{2} \mathrm{SO}_{4}+\mathrm{Al}_{2}\left(\mathrm{SO}_{4}\right)_{3}+12 \mathrm{HF} \uparrow
\end{gathered}
$$

This operation requires 0.48 mole of sulfuric acid for a weight of 32 grams cryolite. Sulfuric acid production releases more calories of $166,000 \mathrm{~mol}$. So the energy of this reaction will be $0.48 \times 166,000=$ 79,680 calories.

The time of regeneration of lead fluoride according to Eq. (11):

$$
\mathrm{HF}+\mathrm{PbClF} \rightarrow \mathrm{PbF}_{2}+\mathrm{HCl} \uparrow
$$


The table indicates thermochemistry 22,000 calories/mole hydrochloric acid, as author has 0.80 mole of lead fluoride and 17,600 calories.

Author must add the regeneration of aluminum fluoride, after the hydrolysis of aluminum sulphate (Eq. (8)) with sodium sulphide according to reaction:

$$
\begin{gathered}
\mathrm{Al}_{2}\left(\mathrm{SO}_{4}\right)_{3}+3 \mathrm{Na}_{2} \mathrm{~S}+6 \mathrm{H}_{2} \mathrm{O} \rightarrow \\
3 \mathrm{Na}_{2} \mathrm{SO}_{4}+3 \mathrm{H}_{2} \mathrm{~S} \uparrow 2 \mathrm{Al}(\mathrm{OH})_{3} \downarrow \\
3 \mathrm{HF}+\mathrm{Al}(\mathrm{OH})_{3} \rightarrow \mathrm{AlF}_{3}+3 \mathrm{H}_{2} \mathrm{O}
\end{gathered}
$$

Release a considerable amount of energy 266,000 calories for aluminum fluoride and 205,000 Mole for 3 molecules of water involved in the reaction: 266,000 $+205,000 \times 0.52$ mole $=244,920$ calories.

Author must replenish sodium chloride before returning to the sea; this operation is done after sulfate reduction (Eq. 9) and hydrolysis is known as sodium sulphide.

$$
\begin{gathered}
2 \mathrm{HCL}+\mathrm{Na}_{2} \mathrm{~S}+\mathrm{H}_{2} \mathrm{O} \rightarrow \\
2 \mathrm{NaCL}+\mathrm{H}_{2} \mathrm{~S} \uparrow+\mathrm{H}_{2} \mathrm{O}
\end{gathered}
$$

Release: More than 98,360 calories/mole; author did that 0.46 mole either: $0.46 \times 98,360=45,245$ calories.

Thus the total recycling of elements gives: 244,920 $+17,600+45,245+79,680$ for a total of 387,445 calories per liter of desalinated seawater (concentration 35 grams/liter).

This amount of energy must be added with solar energy via biomass energy. Author estimated 3,000 hectares of land planted with bamboo, plant whose growth is exceptional (3 to $100 \mathrm{~cm} /$ day) irrigated with water from desalinated sea rich in potassium, which can ensure a constant power of 3,000 Megawatts, clean and renewable.

Analysis of Energy Expenditure: In fact, the only reactions that require energy are the decay of the compound sodium fluoride aluminum $\mathrm{Na}_{3} \mathrm{AlF}_{6}$ by sulfuric acid and the reduction of sodium sulphate with carbon; all these operations are at a temperature of $250{ }^{\circ} \mathrm{C}$ minimum:

$$
\begin{gathered}
6 \mathrm{H}_{2} \mathrm{SO}_{4}+2 \mathrm{Na}_{3} \mathrm{AlF}_{6} \rightarrow \\
3 \mathrm{Na}_{2} \mathrm{SO}_{4}+\mathrm{Al}_{2}\left(\mathrm{SO}_{4}\right)_{3}+12 \mathrm{HF} \uparrow
\end{gathered}
$$

For this operation, author has a mass of 32 grams of $\mathrm{Al}_{2}\left(\mathrm{SO}_{4}\right)_{3}$ to treat with 0.46 mole $\mathrm{H}_{2} \mathrm{SO}_{4}$ or 45 grams $\times 250$ degrees $=11,270$ calories.

The amount of sodium sulfate is 0.232 moles whose reduction requires 45,000 calories/mole [8] (New treatise on inorganic chemistry Masson and Company) or $0.232 \times 45,000=10,500$ about calories.

$$
\mathrm{Na}_{2} \mathrm{SO}_{4}+2 \mathrm{C} \rightarrow 2 \mathrm{CO}_{2} \uparrow+\mathrm{Na}_{2} \mathrm{~S}
$$

Although author take into account the energy required for sulphate reduction, with the advancement of biology that sulphate reduction can be carried out easily and for free with the sulphate-reducing bacteria fed and vegetable waste.

After subtracting the energy costs, recycling brings a gain of $387,445-21,770=365,675$ calories per liter of desalinated water. Author has no quantified hydrogen for Eq. (9). More solar energy is supplied by biomass via bamboo cultivation [9].

Personal assessment of this process: This method has a great advantage over others $[10,11]$ because it uses lead, a much cheaper metal, rather than copper and silver. Besides, lead has lost its importance in everyday applications because of its toxicity. And author used it safely, because after treatment with magnesium, not a lead ion remains in desalinated water (Eq. (8)) and further the amount of residual hydrogen is considerable (Eq. (9)).

Lastly, it will add about 3 grams/L sulfuric acid to offset the precipitation of $\mathrm{SO}_{4}{ }^{2-}$ ions by lead (Eq. (3)) and have potassium sulfate:

$$
\mathrm{H}_{2} \mathrm{SO}_{4}+2 \mathrm{KOH} \rightarrow \mathrm{K}_{2} \mathrm{SO}_{4}+2 \mathrm{H}_{2} \mathrm{O}
$$

Then the addition of lime $\left(\mathrm{Ca}(\mathrm{OH})_{2}\right.$ will control the fluoride content in the water, namely, the safe rate of 1 to 2 p.p.m or $\mathrm{mg} /$ liter.

\section{Conclusion}

Unpretentiously, author believes to have demonstrated that seawater can be desalinated in the best conditions without impact on the environment which becomes more fragile. In addition to water and potassium, for a more productive and sustainable 
agriculture, the new method provides energy. With respect, author implores the editorial board to welcome the study so that interested parties can benefit, because if the work is not supported by a major association or editor, it will be failed.

\section{Acknowledgments}

Author's thanks to scholars Arrhenius, Berthollet, Dalton, Faraday, Lavoisier, Mendeleïev, Moissan who has isolated the fluorine indispensable in the precipitation of sodium $\mathrm{Na}^{+}$in seawater and the other who have structured the chemistry, the quoted authors. Author applied rigorously their work to achieve desalinating seawater without distillation, RO and avoid energy spending enormous.

\section{References}

[1] Timm, J. A. 1968. General Chemistry. Simmons College: Mc Graw-Hill.

[2] Open Chemistry Database. 2006. "Aluminum Fluoride."
Open Chemistry Database. Accessed 2016. https://pubchem.ncbi.nlm.nih.gov/compound/10129892.

[3] Charlot, G. 1969. Chemical Reactions in Solution. France: Masson \& Cie.

[4] Web Archive. "Chemical Elements." Centre de Research en Calcul Thermochimique. Accessed 2016. http://www.crct.polymtl.ca.

[5] Binet, P., and Brunel, J. P. 1967. Plant Physiology. Paris: Doin Editions.

[6] Weisz, P. B. 1966. Elements of Biology. Montreal: Mc Graw-Hill.

[7] Duchaufour, P. 1970. Handbook of Soil Science. France: Masson \& Cie: 364-8.

[8] Masson. 1985. New Treatise on Inorganic Chemistry. By Pascal Paul Member of the Academy of Sciences of France.

[9] Chadefaud, H. M., Ferré, Y., Feldmann, J., Gaussen, H., and Grassé, P. P. 1963. Botany. France: Masson \& Cie.

[10] Bayard, G. 2013. "New Method for Desalination of Seawater." Journal of Chemistry and Chemical Engineering 7 (9): 892-6.

[11] Bayard, G. 2016. "Other Seawater Desalination Method." Journal of Chemistry and Chemical Engineering 48-51. 